\title{
ResearchOnline@JCU
}

This is the author-created version of the following work:

Mills, Reece, Tomas, Louisa, and Lewthwaite, Brian (2019) The impact of student-constructed animation on middle school students' learning about plate tectonics. Journal of Science Education and Technology, 28 (2) pp. 165-177.

Access to this file is available from:

https://researchonline.jcu.edu.au/55788/

Please refer to the original source for the final version of this work:

https://doi.org/10.1007/s10956\%2D018\%2D9755\%2Dz 


\section{The Impact of Student-Constructed Animation on Middle School Students' Learning about Plate Tectonics}

Journal: Journal of Science Education and Technology

\section{Authors:}

1. Reece Mills (Corresponding author) Faculty of Education

Queensland University of Technology

Victoria Park Road

Kelvin Grove, QLD, 4059

ORCID: 0000-0002-2156-7677

Email: Reece.Mills@qut.edu.au

Phone: +61 731383345

Twitter: @DrReeceMills

\section{Brian Lewthwaite}

College of Arts, Society \& Education

James Cook University

1 James Cook University Drive

Townsville, QLD, 4811

Email: Brian.Lewthwaite@jcu.edu.au

\section{Louisa Tomas}

College of Arts, Society \& Education James Cook University

1 James Cook University Drive

Townsville, QLD, 4811

Email: Louisa.Tomas@jcu.edu.au

Phone: +61 747816117 
The Impact of Student-Constructed Animation on Middle School Students'

Learning about Plate Tectonics 


\begin{abstract}
There is a need for research-informed instructional approaches that promote school students' deep conceptual understanding of abstract geological concepts. Given that a type of learner-constructed stop-motion animation, 'slowmation', has been shown to offer affordances for learning in science preservice teacher education, we extended its application to middle school and investigated the impact of the construction process on students' learning about plate tectonics. Drawing upon theoretical notions of knowledge reconstruction, this mixed methods case study explored two research questions that concerned the extent to which the slowmation construction process influenced students' conceptual understanding about plate tectonics, and how students' learning was facilitated by the slowmation construction process. The participants were Year 9 students $(n=52)$ who constructed slowmations in small groups to explain the geological processes that occur at tectonic plate boundaries. Data were generated using a twotiered multiple-choice test instrument, the GeoQuiz, which we designed and validated, and audiorecordings of students working together as they researched, planned, and constructed their slowmations. A significant improvement was found in students' GeoQuiz scores, from pretest to posttest, which indicates their conceptual understanding improved over the course of the construction process. Analysis of the qualitative data found that students' ideas increased in sophistication through 'teachable moments', wherein students learnt through dialogic teacherstudent and student-student exchanges. We assert that such exchanges ought to be viewed as an integral part of the slowmation construction process itself. While the study's findings support existing research that suggests representation-based activities are effective for student learning of geological phenomena, they also raise important questions about how to best engage middle school students in the construction of a slowmation.
\end{abstract}


Keywords: Earth science education; conceptual change; knowledge reconstruction; digital media; slowmation. 
The Impact of Student-Constructed Animation on Middle School Students'

Learning about Plate Tectonics

It is well-known within the literature that school students experience considerable difficulty in coming to understand geological concepts and processes (Francek, 2013; Mills, Tomas, \& Lewthwaite, 2016). Research has shown that students have incorrect or incomplete understandings about key ideas such as rock formation and classification (Froyland, Remmen, \& Sorvik, 2016), and plate tectonics (Dolphin \& Benoit, 2016; Mills, Tomas, \& Lewthwaite, 2017), and they struggle to comprehend the vast temporal and spatial scales inherent to learning about geology (Yoon \& Peate, 2015). To illustrate, an Australian study that explored middle school students' $(n=95)$ conceptions about geological topics found that students had a limited understanding of plate tectonics, the formation of landforms, and the occurrence of geological events such as earthquakes at tectonic plate boundaries (Mills et al., 2017). Some of the most common alternative conceptions included students' belief that tectonic plates are located deep underground and are not exposed at the Earth's surface (40\%); tectonic plate boundaries are located at the edges of continents (23\%); and earthquakes occur at tectonic plate boundaries when two tectonic plates crash together (32\%) (Mills et al., 2017). Of particular concern is the widespread durability of students' alternative conceptions about plate tectonics; a problem which has also been reported internationally (e.g., American Association for the Advancement of Science [AAAS], 2015; Francek, 2013; Gobert, 2000).

This research suggests that instruction and learning about geological topics requires greater attention in science education research. There are calls for specialized instructional approaches within this discipline that address students' firmly held alternative conceptions and encourage deep levels of understanding (Francek, 2013; Mills et al., 2016). Instructional approaches that require the iterative construction and reconstruction of multiple representations, 
such as 'slowmation' (i.e., a form of stop-motion animation), are particularly effective for this type of learning. Slowmation has proven merit in preservice teacher education. In this context, it has been effective in supporting the identification and resolution of preservice teachers' alternative conceptions, as there are many opportunities for knowledge reconstruction when information is 'translated' between representations (e.g., Hoban \& Nielsen, 2013, 2014). While recent studies have investigated the value of slowmation for preservice teachers' or other undergraduate students' learning in science (Hoban, Loughran, \& Nielsen, 2011; Hoban \& Nielsen, 2012, 2013, 2014; Nielsen \& Hoban, 2015; Nielsen, Hoban, \& Hyland, 2017; Paige, Bentley, \& Dobson, 2016; Wishart, 2017), no studies have considered how this type of instructional approach can be used in Earth science to support the development of middle school students' ideas about complex geological concepts. In response to this gap in current scholarship, and the apparent alignment between the pedagogical demands of Earth science education and the affordances of slowmation for student learning, we investigated the influence of the slowmation construction process on middle school students' learning about plate tectonics; an important geological concept relevant to all of Earth's physical systems and processes.

In the sections that follow, we begin by reviewing two complementary theoretical perspectives about knowledge reconstruction, conceptual change and learning progressions, which informed our view of student learning in this study, as well as instructional approaches that have been used to teach plate tectonics. Next, we position slowmation as an instructional approach that can support knowledge reconstruction, and one that warrants further investigation in contexts beyond preservice teacher education, such as the middle years, and specifically within the Earth science discipline. 


\section{Theoretical Perspectives on Knowledge Reconstruction}

Early views of learning in science assumed that students have no knowledge of a topic prior to formal instruction, and the mind was viewed as a tabula rasa to be filled with science information (Gilbert, Osborne, \& Fensham, 1982). Such views are in stark contrast to the constructivist theories that now inform science education. Constructivism recognises the influence of students' prior experiences on how scientific phenomena are perceived and interpreted, and emphasises the importance of students' existing conceptions in the construction and reconstruction of knowledge (Taylor, 2015). For the past three decades, much science education research has investigated students' existing knowledge from a 'conceptual change' perspective. This perspective is concerned primarily with how students' understanding of a given topic changes over time, and more specifically, "how naïve, nonscientific, or 'wrong' conceptions develop to become improved, scientific, or 'correct' concepts" (von Aufschnaiter \& Rogge, 2015, p. 209).

Students' existing knowledge has also been considered from a 'learning progressions' perspective; that is, "how students' understanding of big ideas may increase in sophistication over time" (Plummer \& Maynard, 2014, p. 905). Student learning from this perspective is generative, sequential and connected, as students' initial understandings of a given concept are built upon in 'levels of achievement' or 'stages' that are developmentally incremental and interrelated (Corcoran, Mosher, \& Rogat, 2009; Duschl, Maeng, \& Sezen, 2011). Rather than emphasising the replacement or modification of students' alternative conceptions with scientific concepts (as is the case with conceptual change theories), a learning progressions perspective gives greater consideration to students' actual understandings and how they may progress. As such, while conceptual change perspectives are concerned with the product of students' thinking, 
learning progressions are concerned with the ways that students' thinking develops over time (Corcoran et al., 2009).

Importantly, both perspectives contend that learning occurs through knowledge reconstruction and purposeful instruction. While the exact causal mechanisms and processes of conceptual change are contested, and there are multiple frameworks through which student learning can be viewed, common to all is the broad notion that, "conceptual change requires fundamental changes in the content and organisation of existing knowledge, as well as the development of new learning strategies for deliberate knowledge restructuring" (Vosniadou, 2013, p. 1). Similarly, researchers of learning progressions acknowledge that the development of student thinking may proceed as a series of increasingly complex schemes that are modified, broken down and rebuilt to take account of new inputs from instruction (Corcoran et al., 2009).

In the current study, the influence of the slowmation construction process on student learning was investigated with notions of both conceptual change and learning progressions theories in mind. While the change in students' conceptions from 'alternative' to 'scientific' was measured, in alignment with similar studies that have explored students' conceptual change in Earth and space science (e.g., Trundle \& Bell, 2010; Ucar, Trundle, \& Krissek, 2011), the progression of students' specific ideas was also given consideration, in alignment with the more recent learning progressions research in Earth and space science (e.g., Plummer \& Maynard, 2014; Plummer et al., 2015). It is to be noted that, in this study, we did not aim to develop and validate a learning progression for plate tectonics; rather, we employed two conceptually similar learning theories (Duschl et al., 2011) to examine both the products of students' thinking, and the ways that their thinking developed in response to an instructional approach. Our adoption of this multi-theoretical position is justified by other authors' assertions that the emergence of learning progressions is a 'new paradigm' in science education and should be accompanied by a variety of 
approaches to analysing teaching and learning from this perspective (Corcoran et al., 2009; Duschl et al., 2011).

\section{Teaching for Learning about Plate Tectonics}

Studies that have investigated knowledge reconstruction in Earth and space science have increased over the past two decades. Instructional interventions have included the use of natural observations (e.g., Trundle, Atwood, \& Christopher, 2002); physical models (e.g., OganBekiroglu, 2007); simulations (e.g., Trundle \& Bell, 2010); student-constructed animation (e.g., Nielsen \& Hoban, 2015); analogy (e.g., Blake, 2004); cognitive conflict (e.g., Tsai \& Chang, 2005); and refutational text (e.g., Broughton, Sinatra, \& Reynolds, 2010). Among these studies, instructional approaches that focus specifically on school students' learning about plate tectonics are scarce. We found only one study that reported that representation-based instruction positively impacted school students' conceptual understanding of tectonic plate boundaries (Nichols, Gillies, \& Hedberg, 2016). In this study, a representation-rich teaching and learning sequence was enacted, wherein the teacher and students used multiple representations, including diagrams, models and verbal explanations, to learn about types of tectonic plate boundaries. The students were encouraged to interpret, explain and construct representations, such that learning occurred through students' developing representational competency (diSessa, 2004). Other studies have examined undergraduate students' learning about plate tectonics or other closely related geological phenomena, such as the formation of mountains or volcanoes, and the occurrence of geological events such as earthquakes. These studies have predominantly used technologyaugmented instruction (e.g., Geographic Information Systems ${ }^{\mathrm{TM}}$ or Google Earth ${ }^{\mathrm{TM}}$ ) to enhance students' learning (e.g., Bitting, McCartney, Denning, \& Roberts, 2018; Bodzin, Anastasio, Sharif, \& Rutzmoser, 2016). 
Technology-enabled instructional approaches, particularly those that support students to construct representations of geologic concepts, such as slowmation (Hoban, 2005, 2007), have become increasingly common as learning technologies have become more advanced and accessible (Mills et al., 2016). Slowmation is a type of animation created from a series of still digital photographs that are displayed in quick succession. Constructing a slowmation involves three stages: (1) planning; (2) chunking and sequencing information; and (3) constructing and reconstructing information (adapted from Loughran, Berry, Cooper, Keast, \& Hoban, 2012). In the planning process, students research a topic and plan a storyboard. In the next phases, they construct and reconstruct multi-modal, two- or three-dimensional models of scientific phenomena using a mobile device or digital camera to take photographs as they manipulate the models to demonstrate a concept or process. The photographs are then displayed at about two frames per second using computer software such as MovieMaker ${ }^{\mathrm{TM}}$, or an application such as MyCreate ${ }^{\mathrm{TM}}$.

Slowmation has been shown to offer a range of affordances for knowledge reconstruction. Existing research conducted in preservice teacher education contexts has found that slowmation construction is effective in supporting science preservice teachers to identify and change their alternative conceptions of science concepts or processes (Hoban \& Nielsen, 2012, 2014; Nielsen \& Hoban, 2015). In these studies, preservice teachers "translated" information between several modes of representation (i.e., written notes from research, storyboard, models, digital photographs, and final animation) in a "cumulative semiotic progression" during the construction process (Hoban et al., 2011, p. 1002). This afforded multiple opportunities for knowledge reconstruction, as the preservice teachers worked to produce scientifically accurate representations, and engaged in scientific reasoning and cogenerative dialogue about their representations with their peers (Hoban \& Nielsen, 2014). 
Although these studies recommend the application of slowmation to school-aged learners, very little empirical research has explored this possibility. We are only aware of two published conference proceedings (Hoban, Ferry, Konza, \& Vialle, 2007; Kidman \& Hoban, 2009) and two published journal articles (Brown, Murcia, \& Hackling, 2013; Jablonski, Hoban, Ransom, \& Ward, 2015) that have investigated the value of slowmation in a middle school science context. This paucity of research calls for further investigation into how middle school students learn from slowmation construction.

\section{Summary and Research Questions}

Contemporary views of student learning in Earth science education posit that developing conceptual knowledge requires “reconceptualizations" of students' existing ideas, as they are "broken down and rebuilt to take account of ... new inputs from instruction" (Corcoran et al., 2009, p. 18). This type of learning calls for "effective instructional conditions" (Duschl at al., 2011, p. 131). Notwithstanding the importance of mapping students' conceptual change or learning progressions for important science concepts over time, which has been the extent of emerging literature, there remains an absence of inquiry into instructional approaches that support this type of learning, particularly within the Earth science discipline (Francek, 2013; Mills et al., 2016), and, more specifically, in a middle school context (Mills, 2017).

In response to this gap in current scholarship, we investigated the impact of the slowmation construction process on middle school students' understanding of plate tectonics, given that it has been shown to facilitate knowledge reconstruction in adult learners (Hoban \& Nielsen, 2013, 2014). The research questions that guided our study were: (1) To what extent does the process of constructing a slowmation impact students' conceptual understanding about plate tectonics, from pretest to posttest? and (2) How does the process of constructing a slowmation influence students' conceptual understanding about plate tectonics? Our second research question 
is particularly important given that very few instructional interventions listed in the previous section have examined how students' geological knowledge is reconstructed using qualitative research methods (Mills et al., 2016). In other words, existing studies have demonstrated an increase in the sophistication of students' ideas from pretest to posttest (e.g., Bitting et al., 2018; Blake, 2004), but have not determined the instructional mechanisms that account for students' learning. In the current study, we seek to identify causal mechanisms for middle school students' knowledge reconstruction during the slowmation construction process. The following sections will present an overview of the research design, and the methods of data generation and analysis that we employed to answer the research questions.

\section{Research Design and Procedures}

This mixed methods case study (Creswell, 2015; Stake, 1995) was conducted with two Grade 9 science classes (13-14 years of age) and their teachers, Ms. Peters and Mr. Jones (pseudonyms), at a college located in South East Queensland, Australia. The students were completing a 10-week unit of work called Changing Earth (Department of Education, Training, and Employment [DETE], 2014), which was common to all Queensland students enrolled in public (state) schools at the time this research was conducted. This unit of work, derived from the Earth and Space Sciences sub-strand of the Foundation to Year 10 Australian Curriculum:

Science (Australian Curriculum, Assessment and Reporting Authority [ACARA], 2017), explores a range of concepts, including the structure and composition of the Earth; continental drift and plate tectonics; and the formation of landforms or occurrence of geologic events, such as earthquakes, at tectonic plate boundaries.

Students from the two case study classes $(n=52)$ worked in pairs or groups of three to coconstruct a slowmation representation over four 70-minute science lessons with their respective classroom teacher (students chose their own groups and these were amended by the teacher, if 
she/he deemed necessary). The slowmation construction process implemented in this study comprised of three broad stages: planning, construction, and presentation (adapted from Loughran et al., 2012). During the planning phase, students researched a type of tectonic plate boundary using the Internet, and created a storyboard for their slowmation representations. The storyboard showed what materials the students would manipulate, and how they would be manipulated between each still photograph in order to represent their chosen tectonic plate boundary. Students had a range of craft materials available for use, including colored paper, modeling clay, sponges, pipe cleaners, paddle-pop sticks, markers, and labels. In the construction phase, students constructed, manipulated, and photographed their representations of a tectonic plate boundary using iPads ${ }^{\mathrm{TM}}$ and the $M y$ Create $^{\mathrm{TM}}$ application. Students used the application to display the photographs at two frames per second and added narration that explained the relevant geological processes. Finally, students viewed their peers' animations in the presentation phase, such that all students learnt about all types of tectonic plate boundaries. Students in the current study did not receive any formal instruction on tectonic plate boundaries prior to their participation in the slowmation construction process.

Over the course of the study, students were encouraged to work independently in small groups to translate information between representations. The role of the classroom teacher was to move between groups of students and prompt them to verbalize their thinking and explain their approach to completing each of the stages. The first author, who was responsible for data collection during the study, was present during these lessons, and adopted an observer-participant role, assisting with these tasks only if approached by a student. It is to be noted that although students were encouraged to work independently in small groups, we had little control over the teachers' and students' perspectives of learning in science, nor the type of learning environment that was normally established in the science classrooms. 
A mixed methods research design that employed both quantitative and qualitative research methods was chosen to develop a deeper understanding of our research questions than either approach might afford individually (Creswell, 2015). Specifically, quantitative analysis of students' responses to the GeoQuiz was complemented by qualitative analysis of audiorecordings of students as they worked together to research, plan, and construct their slowmations. While the GeoQuiz enabled us to quantify any changes in students' understanding of plate tectonics over the course of the study, we anticipated that the qualitative recordings would provide a more nuanced insight into the progression of students' conceptions. As the current study seeks to establish the learning potential of the instructional approach, particularly given the paucity of slowmation studies with school-aged students, we deemed it unnecessary to collect data from a comparison group. Both methods of data collection used in the study are outlined below.

\section{Quantitative data source and analysis}

A two-tiered multiple-choice test, the GeoQuiz, was designed and validated for use in this study. This type of test instrument was chosen because it is particularly well suited to measure deep conceptual understanding. Although researchers have used variations of multiple-choice tests to achieve this aim in Earth science, the use of a tiered multiple-choice test is a more "sensitive and effective way of assessing meaningful learning" (Treagust, 2006, p. 3, emphasis added). It also overcomes the limitation of a traditional multiple-choice test whereby a student can rote-learn or guess content-only items.

The GeoQuiz was used to identify students' conceptual understanding about plate tectonics. It comprises of nine questions that examine 14 propositional knowledge statements (e.g., 'At divergent plate boundaries, lithospheric plates move apart') derived from the Changing Earth unit (DETE, 2014) (refer to Table S1 for the full range of propositional knowledge 
statements that were tested). The test was administered to all students in the two case study classes $(n=52)$ on two occasions, before and after they constructed their slowmations, to determine the extent to which the process impacted their conceptual understanding. While the first tier of each item on the test is a multiple-choice content question, the second tier comprises of a set of possible reasons for the answer given (generally four), which consist of the correct answer, any identified alternative conception/s from our prior research (Mills et al., 2017), and a wrong answer (Figure 1). The full GeoQuiz is available in the online supplementary material accompanying this paper.

\section{Question 5}

What causes Earth's tectonic plates to move?

A. Gravity

B. Heat

C. Earth's movement in space

D. Ocean currents

The reason for my answer is because:

1. Earth's spin on its axis causes tectonic plates to move

2. Molten rock in Earth's mantle boils and the bubbles cause tectonic plates to move

3. Molten rock in Earth's mantle rises and falls creating convention currents that cause tectonic plates to move

4. Earth's oceans push against continents and cause tectonic plates to move

Figure 1: An example item from the GeoQuiz.

The process that was followed to develop the GeoQuiz was foregrounded by Treagust (1988), and involved three tasks: (1) Defining the Earth science content; (2) Researching students' alternative conceptions (Mills et al., 2017); and (3) Developing and validating the test instrument (Figure 2). In scoring students' responses to the GeoQuiz, both the content and reasoning tiers of the test had to be correct for students to correctly answer the question, consistent with how two-tiered multiple-choice tests have been scored in the science education literature (e.g., Tsui \& Treagust, 2010). 
The trustworthiness of the GeoQuiz was established in multiple ways. First, a panel of three middle school science teachers from the research site (which included the teachers involved in the current study, Ms. Peters and Mr. Jones) was consulted throughout the entire development process, in order to write the propositional knowledge statements that were tested, and to develop a concept map that relates the statements to each other. These tasks were important as they allowed us to consider carefully the nature of the content, and to ensure that it was internally consistent. According to Treagust (1988), "this is a reliability check that the underlying concepts and propositional statements are indeed examining the same topic area" (p. 162). Second, a specification grid was devised to ensure that the test instrument fairly covers the propositional knowledge statements and the topic concepts (Table S2). Third, Cronbach's alpha coefficient was calculated as 0.53 , which is higher than the 0.50 threshold proposed for multiple-choice tests (Nunnally, 1978).

(1) Defining the content

- Identified propositional knowledge statements required for understanding of the concepts covered in the Year 9 C2C unit 'Changing Earth' (DETE, 2014)

- Created a concept map of the propositional knowledge statements

- Validated the propositional knowledge statements and concept map with experienced science teachers and science teacher educators

(2) Researching students' alternative conceptions (Mills et al., 2017)

- Searched the literature for common alternative conceptions about continental movement, tectonic plates, and the formation of landforms at tectonic plate boundaries (including the occurrence of geologic events like earthquakes)

- Conducted semi-structured interviews-about-instances (Osborne \& Gilbert, 1979) with students to identify additional alternative conceptions

(3) Developing and validating the test instrument

- Developed an initial test instrument

- Designed a specification grid to ensure that the test instrument fairly covers the propositional knowledge statements underlying the topic

- Developed the final test instrument and validated the test using pretest data

Figure 2: Approach to the design and validation of the GeoQuiz.

Item and statistical analyses were both performed on the GeoQuiz data. Any changes in students' conceptions from pretest to posttest were initially analysed using descriptive statistics; 
specifically, the frequency of students with scientific and alternative conceptions at pretest and posttest was compared. Following this, a paired samples $t$-test was carried out on students' overall test scores to determine if the changes in students' conceptual understanding were statistically significant from pretest to posttest.

\section{Qualitative data source and analysis}

Audio-recordings of students' reasoning as they worked in small groups to plan, research, and construct their slowmations served as the qualitative data in this study. Three groups of students from each of the two classes (i.e., six groups of students, $n=18$ ) were audio-recorded throughout the construction of their slowmation, as they discussed their ideas during the planning and construction process. These students were chosen to be audio-recorded after a discussion with their classroom teacher, who indicated that they would be capable of articulating clearly their thinking during the construction process.

To facilitate the analysis of the student audio data, recordings were transcribed using pseudonyms for the students' and teachers' names. Once transcribed, an initial exploratory analysis was carried out, whereby the transcripts were read several times in their entirety to discern what was important in the data and what was not. Then, initial coding procedures were employed to build a foundation for further coding cycles (Saldaña, 2013). In doing so, the data were broken down into discrete parts according to the three stages slowmation construction (planning, constructing and presenting), before being examined closely, and compared for similarities and differences. Short segments of text were then coded in a manner representative of their meaning. Finally, pattern coding procedures were employed to develop more meaningful and parsimonious categories and themes from the data (Saldaña, 2013). 


\section{Research Findings}

In this section, we present evidence to support our claim that students' conceptual understanding about plate tectonics improved during the slowmation construction process. We found that students had more scientific understandings about plate tectonics at posttest, and that their ideas increased in sophistication through 'teachable moments'. In these moments, students' conflicting ideas about plate tectonics, brought to the fore during the slowmation construction process, were resolved through generative dialogic exchanges with their teacher and with each other.

\section{Quantitative findings: Development of students' conceptual understanding}

Changes in students' conceptions from pretest to posttest, as represented by the GeoQuiz data, was initially analysed using descriptive statistics. Overall, our findings showed an increase in the number of students with scientific conceptions and a decrease in the number of students with alternative conceptions, from pretest to posttest (Table 1). In determining whether these changes in students' conceptions were statistically significant, a paired-samples $t$-test revealed a significant improvement in students' mean GeoQuiz scores from pretest $(M=12.29, S D=4.34)$ to posttest $(M=15.08, S D=4.49), t(51)=-6.52, p<0.001$. A large effect size of 0.91 , as measured by Cohen's $d$, was observed (Tabachnick \& Fidell, 2007). This indicates that students' participation in the construction of a slowmation enhanced their conceptual understanding of a range of geological concepts, as measured by the GeoQuiz, including the nature and movement of tectonic plates, tectonic plate boundaries, and the formation of landforms at tectonic plate boundaries (refer to Table S1 for the full list of propositional statements tested by the GeoQuiz). 
Table 1

Students' conceptions about geological concepts including tectonic plates, as identified by the GeoQuiz

\begin{tabular}{|c|c|c|c|}
\hline Item & Reason choice & $\begin{array}{l}\text { Pretest } \\
n=52 \\
(\%)\end{array}$ & $\begin{array}{l}\text { Posttest } \\
n=52 \\
(\%)\end{array}$ \\
\hline 1 & $\begin{array}{l}\text { Tectonic plate boundaries are found at the edges of continents } \\
\text { Tectonic plate boundaries are found at the equator } \\
\text { Tectonic plate boundaries only occur where continents meet oceans } \\
\text { Tectonic plate boundaries are where two tectonic plates meet* }\end{array}$ & $\begin{array}{c}19.2 \\
3.8 \\
9.6 \\
\mathbf{6 3 . 5}\end{array}$ & $\begin{array}{c}19.2 \\
0 \\
3.8 \\
\mathbf{7 5 . 0}\end{array}$ \\
\hline 2 & $\begin{array}{l}\text { Volcanoes are located in places that have a high temperature, like at the equator } \\
\text { When two continental tectonic plates push together, both plates are pushed upward to } \\
\text { form volcanoes } \\
\text { When an oceanic tectonic plate and a continental tectonic plate push together, } \\
\text { the oceanic plate material is pushed downward and melts to form volcanoes* } \\
\text { There is a mountain range located here, and all mountains are volcanoes }\end{array}$ & $\begin{array}{r}13.5 \\
53.8 \\
19.2 \\
1.9\end{array}$ & $\begin{array}{r}11.5 \\
40.4 \\
40.4 \\
3.8\end{array}$ \\
\hline 3 & $\begin{array}{l}\text { Mountains are formed when the edges of two tectonic plates are pushed upward } \\
\text { Mountains are formed when the edge of one tectonic plate is pushed downward, and } \\
\text { one tectonic plate is pushed upward } \\
\text { Mountains are formed when both } 1 \text { and } 2 \text { occur* } \\
\text { Mountains are formed when pieces of rock pile up }\end{array}$ & $\begin{array}{c}48.1 \\
11.5 \\
38.5 \\
1.9\end{array}$ & $\begin{array}{c}11.5 \\
\mathbf{2 5 . 0} \\
0\end{array}$ \\
\hline 4 & $\begin{array}{l}\text { Earth's tectonic plates are located deep within the Earth and are not exposed at the } \\
\text { surface } \\
\text { The outer layer of the Earth, including continents and the ocean floor, consists } \\
\text { of separate tectonic plates* }\end{array}$ & 38.5 & $\begin{array}{l}32.7 \\
60.0\end{array}$ \\
\hline 5 & $\begin{array}{l}\text { Earth's spin on its axis causes tectonic plates to move } \\
\text { Molten rock in Earth's mantle boils and the bubbles cause tectonic plates to move } \\
\text { Molten rock in Earth's mantle rises and falls creating convention currents that } \\
\text { cause tectonic plates to move* } \\
\text { Earth's oceans push against continents and cause tectonic plates to move }\end{array}$ & $\begin{array}{c}19.2 \\
9.6 \\
67.3 \\
3.8\end{array}$ & $\begin{array}{r}3.8 \\
9.6 \\
75.0 \\
11.5\end{array}$ \\
\hline 6 & $\begin{array}{l}\text { Earth's continents and ocean basins move a few centimeters each year* } \\
\text { Earth's continents and ocean basins move a few centimeters over hundreds of years } \\
\text { Earth's continents and ocean basins move a few centimeters over millions of years } \\
\text { The layer beneath Earth's plates moves very rapidly }\end{array}$ & $\begin{array}{c}44.2 \\
38.5 \\
13.5 \\
0\end{array}$ & $\begin{array}{c}\mathbf{5 3 . 8} \\
21.2 \\
23.1 \\
0\end{array}$ \\
\hline 7 & $\begin{array}{l}\text { When two tectonic plates push together for millions of years, the larger tectonic plate } \\
\text { is pushed upward } \\
\text { When two tectonic plates push together for millions of years, the faster moving } \\
\text { tectonic plate is pushed upward } \\
\text { When two tectonic plates push together for millions of years, the more buoyant } \\
\text { tectonic plate is pushed upward* } \\
\text { When two tectonic plates push together for millions of years, the tectonic plate that is } \\
\text { positioned the highest is pushed upward }\end{array}$ & 11.5 & $\begin{array}{l}21.2 \\
7.7 \\
\mathbf{5 7 . 7}\end{array}$ \\
\hline 8 & $\begin{array}{l}\text { When two tectonic plates separate, an empty gap forms between them } \\
\text { When two tectonic plates separate, loose rock fills the gap that forms between them } \\
\text { The continents are separated and oceanic crust material is formed between } \\
\text { them* } \\
\text { A trench forms when oceanic crust material separates }\end{array}$ & $\begin{array}{l}42.3 \\
13.5 \\
26.9 \\
17.3\end{array}$ & $\begin{array}{c}46.2 \\
7.7 \\
\mathbf{2 3 . 1} \\
19.2\end{array}$ \\
\hline 9 & $\begin{array}{l}\text { Earthquakes occur at plate boundaries when two tectonic plates crash together } \\
\text { Earthquakes occur at plate boundaries when two tectonic plates suddenly move apart } \\
\text { Earthquakes occur along breaks in rock where one side moves* } \\
\text { Earthquakes occur when two tectonic plates rub together }\end{array}$ & $\begin{array}{c}21.2 \\
25.0 \\
\mathbf{3 . 8} \\
48.1\end{array}$ & $\begin{array}{l}11.5 \\
11.5 \\
\mathbf{1 7 . 3} \\
57.7\end{array}$ \\
\hline
\end{tabular}

*Note: Scientifically accurate responses are in bold font for ease of reference. The response scores do not always total 100 per cent as some students opted to write their own reasoning choice. 


\section{Qualitative findings: The resolution of students' conflicting ideas through teachable moments}

While the GeoQuiz data revealed significant improvements in students' understanding of plate tectonics, analysis of the qualitative data in this study presented an opportunity to explore students' intermediate ideas about tectonic plate boundaries and how their developing conceptual understanding was facilitated by the slowmation construction process. Our analysis of the six groups' audio-recorded lessons showed that the slowmation construction process afforded teachable moments, wherein students' conflicting ideas and uncertainty about plate tectonics, brought to the fore by the construction process, were resolved through generative dialogic teacher-student exchanges, and, to a lesser extent, through student-student exchanges, particularly as students explained their newfound understanding to their peers. Importantly, we have chosen to use the term 'dialogic' as students learnt through classroom talk; that is, through conversation with the teacher and amongst themselves (Aguiar, 2015). We have chosen to use the term 'exchanges', as the talk often appeared teacher-led, and did not lead to true dialogic 'interactions'. Such interactions are reciprocal and cumulative, as teachers and students build upon each other's ideas (Gillies, 2016).

During these in-the-moment exchanges, students sought help from the teacher on a needto-know basis, and the teacher facilitated students' learning by prompting them to consider the scientific accuracy of their ideas as they conducted research, discussed ideas in their groups, and constructed and manipulated three-dimensional models. The teacher questioned students to encourage their deep thinking about geological processes, and, at times, provided scientific explanations. On occasions across the audio-recorded lessons, students explained their developing understanding to their peers, which, in turn, helped to advance their peers' understanding. While we found that students did not articulate their thinking in-depth during the 
slowmation construction lessons, and their utterances were quite limited at times, the themes we distilled from this data are nonetheless important; they make an original contribution to the literature regarding the affordances of slowmation for bringing about knowledge reconstruction in a middle school learning context, and have implications for future research. In this section, we present two representative narratives, one from each case study class, to illustrate and evidence these claims about how student learning occurred in our study.

Narrative 1: Zach, Trevor, and Joe. In Mr. Jones' class, three students, Zach, Joe and Trevor, constructed a slowmation about divergent continental plate boundaries and the continental rifting process. Zach and Joe began the planning stage by completing the prescribed research questions on the task sheet to determine the direction of plate movement, and the geological processes or landforms that occur:

\begin{tabular}{|c|c|c|}
\hline Turn & Speaker & Dialogue \\
\hline 01 & Zach: & Joe? \\
\hline 02 & Joe: & Yeah? \\
\hline 03 & Zach: & $\begin{array}{l}\text { Is a divergent plate boundary where they move together } \\
\text { and one goes up and one goes down? }\end{array}$ \\
\hline 04 & Joe: & $\begin{array}{l}\text { Um::: yeah. I believe one goes up and one goes down. I } \\
\text { think. }\end{array}$ \\
\hline 05 & Zach: & I'll check. [Zach conducts an Internet search.] \\
\hline 06 & Joe: & [Yeah, that's right.] \\
\hline 07 & Zach: & Okay. They move away and make a trench. \\
\hline 08 & Joe: & Yeah. \\
\hline
\end{tabular}

Initially, Zach and Joe had conflicting ideas about the direction of plate movement and the landforms at a divergent plate boundary; that is, their ideas were inconsistent with a scientific understanding. In turns 03,04 and 06 , the students agreed that the tectonic plates "move 
together", and "one goes up and one goes down". Joe’s tentative response, "I think" (turn 04), suggests that he was unsure about this claim, however. This prompted Zach to conduct an Internet search that appeared to resolve their conflicting ideas. He claimed that the tectonic plates “move away" (turn 07), which is scientifically accurate, and Joe agreed with this in turn 08.

The students also had conflicting ideas about the landforms that occur at this type of tectonic plate boundary. In turns 07 and 08, they agreed that as the tectonic plates "move away", they "make a trench". Unlike the students' ideas about the direction of tectonic plate movement, which was resolved following Zach's research, this conflicting idea persisted throughout the planning stage. After turn 08, when the students were constructing a storyboard for their slowmation, Joe remarked, "Alright, what's the plan? So first we just show them [the tectonic plates] moving apart, right?", to which Zach replied, "Yep. We're just going to show them [the tectonic plates] moving apart, and then we'll show the trench."

Trevor joined Zach and Joe during the construction stage. They began to build and manipulate a three-dimensional model of a divergent plate boundary using two thick sponges, colored cardboard and modeling clay; however, they were uncertain about how to model the formation of a trench. In Excerpt 2, Zach sought help from Mr. Jones in response to the group's uncertainty:

Excerpt 2

$\begin{array}{lll}\text { Turn } & \text { Speaker } & \text { Dialogue } \\ 01 & \text { Zach: } & \begin{array}{l}\text { When two continental ones [plates] move apart, does it } \\ \text { create a trench? }\end{array} \\ 02 & \text { Mr. Jones: } & \text { No, not a trench. It creates what's called a continental rift. } \\ 03 & \text { Zach: } & \text { But- } \\ 04 & \text { Mr. Jones: } & \text { It's kind of like- } \\ 05 & \text { Zach: } & \text { [Just a gap?] }\end{array}$


06

07

08

09

10

11
Mr. Jones: -where the crust thins out and the magma below rises and can erupt onto the surface.

Zach: Do you think we could use this [two pieces of thick sponge] and pull it in half and pretend that's the crack opening?

Mr. Jones: Yeah if you want. You need to show what happens there [pointing to the space that is left from separating the two pieces of sponge].

Trevor: $\quad$ Yeah we have to try and decide. Because originally we thought we were going to put the trench in there but now we're not sure.

Mr. Jones: Isn't red [colored paper on top of the pieces of sponge] continental crust? Continental-continental. So this would be a rift basin where you sometimes have eruptions happening. Maybe show the crust in the basin and have some magma coming up. It can’t stay as an empty gap.

Zach: $\quad$ Yeah:::

In turn 01, Zach was still questioning whether a trench is formed when two continental plates diverge. Mr. Jones explained in turns 02,04 and 06 that a continental rift forms as the lithosphere thins and magma rises to the Earth's surface. Accepting this explanation, the students turned their attention to representing how this process occurs using their model. Zach suggested that they pull the two pieces of sponge apart (turn 07). Mr. Jones prompted the students to consider the scientific accuracy of this model, indicating that they needed to show what happens in the space left by the two separating sponges (turn 08). When Trevor indicated that his group was "not sure" about what to do (turn 09), Mr. Jones explained the formation of a rift basin, after suggesting that the students use the colored cardboard to show the thinning of the Earth's lithosphere (turn 10).

From this exchange, it is evident that Zach perceived a continental rift as a "crack" (turn 07) in the Earth's lithosphere, rather than a thinning of the lithosphere over tens of kilometers. His utterance, "Yeah:::", in turn 11, also suggested that he remained uncertain about how to 
construct a model to represent this landform. Several minutes later, in the same construction

lesson, his conflicting ideas about this were brought to the fore (Excerpt 3):

Excerpt 3

\begin{tabular}{|c|c|c|}
\hline Turn & Speaker & Dialogue \\
\hline 01 & Zach: & $\begin{array}{l}\text { So we'll show them, like, back together and we'll show the } \\
\text { magma joins them back together. }\end{array}$ \\
\hline 02 & Trevor: & It does? \\
\hline 03 & Zach: & $\begin{array}{l}\text { It just fills in the gap. Because the magma hardens because } \\
\text { of the water. Oh no! It's continental. That's right. So what } \\
\text { happens after that? I'm gonna ask Sir. }\end{array}$ \\
\hline 04 & Trevor: & $\begin{array}{l}\text { I'm thinking that it slowly, like, hardens up and becomes } \\
\text { part of the crust. That's why I was flattening it [modeling } \\
\text { clay positioned between the sponges] out. }\end{array}$ \\
\hline 05 & Zach: & {$[\mathrm{Sir} !]$} \\
\hline 06 & Mr. Jones: & Yes? \\
\hline 07 & Zach: & $\begin{array}{l}\text { When magma comes out of the crust, does it, like, harden } \\
\text { and join back together like this? [Zach pushes the two } \\
\text { sponges together.] }\end{array}$ \\
\hline 08 & Mr. Jones: & $\begin{array}{l}\text { Hmm::: not really. It won't fill up with magma. It's more } \\
\text { likely to fill up with water and form a rift lake or a new } \\
\text { ocean basin eventually as it keeps separating. }\end{array}$ \\
\hline 09 & Zach: & Ah! \\
\hline 10 & Trevor: & $\begin{array}{l}\text { Ah I see! Okay. It's like that [points to model]. Alright } \\
\text { that makes sense. }\end{array}$ \\
\hline
\end{tabular}

In Excerpt 3, Mr. Jones explained to Zach that the extension of the continental lithosphere occurs until it separates, and that by this time, the basin that forms is sufficiently deep to be infilled by the ocean (turn 08). It appears that Mr. Jones' explanation helped to resolve the boys' confusion, as indicated by their utterances in turns 09 and 10.

Trevor's remark in turn 04 is also noteworthy. In response to Zach's suggestion that “the magma joins them [the tectonic plates] back together" (turn 01) and "fills in the gap" (turn 03), Trevor said, "I'm thinking that it [the magma] slowly, like, hardens up and becomes part of the 
crust. That's why I was flattening it [modeling clay positioned between the sponges] out." This suggests that Mr. Jones' intervention in Excerpt 2, where he prompted the group to consider the accuracy of their model, encouraged Trevor to think more deeply about how to represent a continental rift. As such, Trevor positioned modeling clay between the sponges and flattened it out to represent lithospheric thinning. In turn 10, after Mr. Jones' explanation, Trevor said “Ah I see! Okay. It's like that" and pointed to the model that he constructed and manipulated earlier.

Narrative 2: Laura and Ellie. In Ms. Peters' class, Laura and Ellie were also constructing a slowmation about divergent continental plate boundaries. Like the previous group, the students began their research by determining the direction of plate movement and landforms at this type of tectonic plate boundary; however, their findings did not fit with their existing understanding about such geological processes (Excerpt 4):

$\begin{array}{lll}\begin{array}{c}\text { Excerpt } 4 \\ \text { Turn }\end{array} & \text { Speaker } & \text { Dialogue } \\ 01 & \text { Laura: } & \begin{array}{l}\text { Does it [the lithosphere] even come back together? I don't } \\ \text { understand. }\end{array} \\ 02 & \text { Ellie: } & \begin{array}{l}\text { No, it wouldn't... Yeah, it would have to because } \\ \text { otherwise the tectonic plates would have holes in them. }\end{array} \\ 03 & \text { Laura: } & \begin{array}{l}\text { I guess so. I'll ask [turns her attention to the teacher]. We } \\ \text { were just, um, a bit confused about divergent plate } \\ \text { boundaries. We're wondering if they separate and then } \\ \text { they come back like that, or they come back like that? }\end{array} \\ 04 & \text { Ms. Peters: } & \text { Neither. They keep separating. }\end{array}$

In this excerpt, the students' conflicting ideas are inconsistent with a scientific understanding. In turn 01, Laura wonders whether divergent plates eventually "come back together", but concedes that she does not understand. Her partner, Ellie, was also uncertain about this new information, but agreed that the plates must move back together again, “... because otherwise tectonic plates would have holes in them" (turn 02). Laura asked Ms. Peters for help 
(turn 03), who confirmed that the tectonic plates continue to separate over time (turn 04).

Following this, Ellie asked for further help, as she was uncertain about how volcanoes form in these areas (Excerpt 5):

$\begin{array}{lll}\begin{array}{c}\text { Excerpt } 5 \\ \text { Turn }\end{array} & \text { Speaker } & \text { Dialogue } \\ 06 & \text { Ellie: } & \begin{array}{l}\text { Okay, so how does a volcano form if the tectonic plates are } \\ \text { separating? }\end{array} \\ 07 & \text { Ms. Peters: } & \text { Well, what do you think? What's a volcano? } \\ 08 & \text { Ellie: } & \text { Magma? } \\ 09 & \text { Ms. Peters: } & \begin{array}{l}\text { Yeah. So if two pieces of lithosphere move apart over } \\ \text { hundreds of thousands of years, what's left? }\end{array} \\ 10 & \text { Ellie: } & \text { A hole? } \\ 11 & \text { Ms. Peters: } & \text { And what's going to fill the 'hole'? } \\ 12 & \text { Ellie: } & \text { Magma? } \\ 13 & \text { Ms. Peters: } & \text { Yeah! } \\ 14 & \text { Ellie: } & \text { Okay! } \\ 15 & \text { Laura: } & \text { [Okay!] }\end{array}$

During this exchange, Ms. Peters questioned Ellie to prompt her thinking about geological processes at divergent plate boundaries by asking a series of questions (turns 07-11). Ellie's final response indicated that magma rises through the lithosphere to fill the "hole" left by two diverging plates (turn 12). At the end of the exchange, both Ellie and Laura appeared satisfied with this explanation, when they exclaimed, "Okay!". In the next lesson, however, during the construction stage, it became apparent that Laura was still confused about the direction of tectonic plate movement at a divergent plate boundary and the formation of a continental rift (Excerpt 6): 
Excerpt 6

$\begin{array}{lll}\text { Turn } & \text { Speaker } & \text { Dialogue } \\ 01 & \text { Laura: } & \begin{array}{l}\text { So cut this [a thick sponge] in half and put one here and } \\ \text { here to make the volcano? Ellie what are you thinking } \\ \text { about? }\end{array} \\ 02 & \text { Ellie: } & \begin{array}{l}\text { Like that. Not folded like that. It's a volcano that forms out } \\ \text { of land- }\end{array} \\ 03 & \text { Laura: } & \text { Out of land? ((Laugh)) } \\ 04 & \text { Ellie: } & \text { Out of magma. } \\ 05 & \text { Laura: } & \begin{array}{l}\text { Are we going to make it so that there are plate boundaries } \\ \text { and build it up? So that it goes inwards sort of? }\end{array} \\ 06 & \text { Ellie: } & \begin{array}{l}\text { What? I don't know what you're talking about. No these } \\ \text { are the plate boundaries. And the plate boundaries spread } \\ \text { apart and then magma comes in between them and then it } \\ \text { [the volcano] forms in the middle of it. }\end{array} \\ & & \text { Oh::: okay! }\end{array}$

In this exchange, Laura wanted to "build up" the lithosphere by pushing two thick sponges "inwards" (turn 05), as she thought this would represent the formation of a volcano at a divergent plate boundary. Following this, Ellie reproduced Ms. Peters' scientific explanation and told Laura that, "the plate boundaries spread apart ... and then it [the volcano] forms in the middle" (turn 06). This demonstration of Ellie's new understanding is significant because it is likely to have come about following Ms. Peters' questioning in Excerpt 5. It also appeared to facilitate Laura's developing understanding, as evidenced by her utterance, “Oh::: okay!", in turn 07.

\section{Discussion and Conclusions}

Given the need for effective instructional approaches that support middle school students' learning of geological concepts, and a greater understanding of how such instruction facilitates knowledge reconstruction, we explored the effectiveness of the slowmation construction process in supporting Year 9 students' conceptual understanding about plate tectonics. Evidence of 
students' conceptual understanding was generated from two data sources: students' responses to the GeoQuiz, before and after their participation in the construction process, and audiorecordings of students working in small groups as they researched, planned, and constructed their slowmations. Analysis of the data revealed that the slowmation construction process enhanced students' conceptual understanding about plate tectonics through teachable moments, wherein students' conflicting ideas and uncertainty about plate tectonics were brought to the fore and resolved in generative dialogic exchanges with their teacher on a need-to-know basis. These new findings suggest that the teachers' pedagogical actions in facilitating generative dialogic exchanges were a crucial part of the slowmation construction process itself for middle school learners, and were the primary driver of students' knowledge reconstruction.

In response to Research Question 1, the analysis of the GeoQuiz data indicates that constructing a slowmation enhanced students' conceptual understanding about a range of concepts related to plate tectonics, including the nature and movement of tectonic plates, and the formation of landforms at tectonic plate boundaries. Overall, we found an increase in the number of students with scientific conceptions and a decrease in the number of students with alternative conceptions, from pretest to posttest. The results revealed that the change in students' GeoQuiz scores was statistically significant. This indicates that constructing a slowmation led to a marked increase in students' conceptual understanding. We observed a particularly large effect size from pretest to posttest $(d=0.91)$, which attests to the effectiveness of slowmation construction in facilitating knowledge reconstruction in the middle years. Further research could be carried out to determine whether the slowmation construction process is more effective than 'teaching as usual' or other representation-construction approaches that may not offer the same affordances as slowmation (such as the multiple modalities of representation and the integration of digital technology). 
In response to Research Question 2, the analysis of audio-recorded lessons revealed the causal mechanisms for middle school students' knowledge reconstruction. It was found that the slowmation construction process afforded teachable moments that addressed students' conflicting ideas about plate tectonics as they were brought to the fore by the construction process. As students in the present study grappled with representing their geological understanding, especially as three-dimensional models, generative dialogic exchanges were crucial in the development of their scientific understandings. During exchanges with their teachers, students were prompted to consider the accuracy of their ideas, questioned to promote deeper thinking about geological concepts and processes, and, at times, provided with necessary scientific explanations.

Importantly, these generative dialogic exchanges appeared to be linked to students' participation in the slowmation construction process, which involved multiple forms of studentconstructed representation (i.e., research notes, storyboards, three-dimensional models, narration, and the final stop-motion animations; Hoban \& Nielsen, 2010). This means that the construction process provided a unique learning context that afforded multiple opportunities for individual students to think deeply about and revise their understandings, as they actively represented and re-represented the scientific information (both physically and mentally) to produce a slowmation, alongside their classroom teacher and peers. It is unlikely that the same discourse would unfold if students were engaged in learning from representations (e.g., looking at a static image or watching a video), rather than with the multiple representations (recall that both groups' conflicting ideas about the content persisted until the construction phase) (see also Mills et al., 2016; Tippett, 2016). As such, we assert that such exchanges ought to be viewed as an integral part of the slowmation construction process itself. 
While our findings concur with research conducted with preservice science teachers about the value of slowmation in learning about science, they suggest that middle school students learn quite differently to adult learners when they construct a slowmation. For preservice teachers, the process of creating a slowmation presented multiple opportunities to engage in dialogic interactions with each other as they translated science information between several modes of representations (i.e., research notes, storyboards, models, digital photographs and the final slowmation) to revise their understandings. Hoban and Nielsen (2014) assert that by "questioning, stating [their] beliefs, seeking evidence and ... making [knowledge] claims" (p. 74), preservice teachers are able to resolve their alternative conceptions as they move through the construction phases. The findings from our study are similar, as the students also had opportunities to resolve their conflicting ideas and uncertainty as they constructed multiple representations of a tectonic plate boundary. The role of the teacher in this process, however, is a new and important finding that has arisen from our application of slowmation to a middle school learning context. Given that "students do not engage in explanatory behaviour, ask thoughtprovoking questions, or draw upon previous knowledge and experiences without some external guidance" (Gillies, 2016, p. 178), we might expect that middle school students require more teacher guidance during the learning process compared to preservice teachers, who are likely to have greater capacity to learn autonomously (cf. Nielsen \& Hoban, 2015).

As we have already pointed out, the teachers' exchanges with their students were crucial in developing conceptual understanding. Mr. Jones and Ms. Peters prompted students to consider the scientific accuracy of their ideas (e.g., Excerpt 2), questioned students to encourage their thinking (e.g., Excerpt 5), and provided scientific explanations of relevant geological phenomena (e.g., Excerpt 3). We found that these exchanges triggered students to revise their conflicting ideas; motivated them to consider how they could represent geological phenomena, such as 
divergent continental plate boundaries, more accurately in their slowmations (cf. Trevor's experience in Excerpt 3); and relay their developing understanding to the peers so that they, too, might come to understand the science content (cf. Ellie and Laura's exchanges in Excerpt 6). Both narratives presented herein illustrate the importance of Mr. Jones and Ms. Peters' pedagogical actions and facilitation of generative dialogue, given that, initially, the students appeared unable to resolve their conflicting ideas amongst themselves.

As highlighted earlier in this paper, the qualitative component of our study was intended to identify the instructional mechanisms that support the development of students' conceptual understanding during the construction of a slowmation (i.e., how they learn), given that this aspect has been given little consideration in other studies that have investigated instructional interventions aimed at improving students' geological knowledge (Mills et al.,, 2016). While the importance of the teacher in resolving students' conflicting ideas in this context is clear, it raises questions about how students can be better supported to construct and defend their own original representations, based on their own ideas and reasoning. At times during the slowmation construction process, Mr. Jones and Ms. Peters were quick to offer students a scientific explanation in an attempt to enhance their understanding. Herein lies a risk that students might transpose their teacher's explanations of scientific phenomena, rather than their own ideas, when constructing slowmations. We believe that more attention should be paid to teachers' pedagogical repertoire and the type of classroom talk it enables, so as to position teachers as 'facilitators of learning' rather than 'providers of knowledge', and more effectively realize the potential for slowmation to bring about knowledge reconstruction. To achieve this, it seems necessary for both the teacher and students to view learning as an active process of knowledge construction and reconstruction. For the teacher, this could include eliciting students' pre-instructional ideas; providing opportunities for students to experience new phenomena and establish a shared 
understanding to build upon; facilitating group and whole-class discussions; and asking questions that support students to articulate their understandings (Harlen, 2010). For students, this could include explicating and discussing their ideas, reasoning and understanding; using their ideas to try to understand new phenomena; modifying their ideas in light of their experiences; and developing bigger ideas from smaller ones (Harlen, 2010). It is clear that greater consideration needs to be given to the broader pedagogy that surrounds the enactment of slowmation in school learning contexts such that its representational affordances can be fully realized.

This research makes an important contribution to the limited number of studies that have explored the use of slowmation with school-aged learners, and offers new insights into how student-constructed stop-motion animation can develop their conceptual understanding of geological phenomena. While constructing a slowmation appears to offer great affordances for student learning, the students in our study appeared to look to their teachers to resolve their conflicting ideas when uncertainty arose in their groups. Further research is needed to investigate how opportunities for knowledge reconstruction can be enhanced by supporting students to engage in dialogic interactions with their peers, with a view to develop their scientific understandings and facilitate the construction of scientific representations that reflect their own thoughts and reasoning. This line of inquiry will call for greater consideration of the pedagogy used to enact complex representation construction activities, like slowmation, that engage middle school students in knowledge reconstruction.

\section{Supplementary Material}

The following supplementary material is linked to the online version of this paper: the GeoQuiz; and Tables S1 and S2. 


\section{Acknowledgement}

The authors wish to thank Associate Professor Donna King at QUT for her useful

comments on earlier versions of the manuscript.

\section{References}

Aguiar, O. (2015). Dialogic teaching and learning. In R. Sunstone (Ed.), Encyclopaedia of science education (pp. 310-315). Netherlands: Springer.

American Association for the Advancement of Science. (2015). AAAS science assessment. Retrieved from: http://assessment.aaas.org/topics/PT\#/

von Aufschnaiter, C., \& Rogge, C. (2015). Conceptual change. In R. Sunstone (Ed.), Encyclopaedia of science education (pp. 209-218). Netherlands: Springer.

Australian Curriculum, Assessment and Reporting Authority. (2017). Science: Curriculum. Retrieved from https://www.australiancurriculum.edu.au/f-10-curriculum/science/

Bitting, K., McCartney, M., Denning, K., \& Roberts, J. (2018). Conceptual learning outcomes of virtual experiential learning: Results of google earth exploration in introductory geoscience courses. Research in Science Education, 48(3), 533-548.

Blake, A. (2004). Helping young children to see what is relevant and why: Supporting cognitive change in earth science using analogy. International Journal of Science Education, 26(15), 1855-1873.

Bodzin, A., Anastasio, D., Sharif, R., \& Rutzmoser, S. (2016). Using a web GIS plate tectonics simulation to promote geospatial thinking. Journal of Geoscience Education, 64(4), 279-291.

Broughton, S., Sinatra, G., \& Reynolds, R. (2010). The nature of the refutation text effect: An investigation of attention allocation. The Journal of Educational Research, 103(6), 407-423.

Brown, J., Murcia, K. \& Hackling, M. (2013). Slowmation: A multi-modal strategy for engaging children with primary science. Teaching Science, 59(4), 14-20.

Corcoran, T., Mosher, F., \& Rogat, A. (2009). Learning progressions in science: An evidenced-based approach to reform. (CPRE Report). Philadelphia, PA: Consortium for Policy Research in Education.

Creswell, J. (2015). A concise introduction to mixed methods research. Thousand Oaks, CA: Sage.

Department of Education, Training and Employment. (2014). Changing earth. Retrieved from https://www.scootle.edu.au/ec/p/home

diSessa, A. (2004). Metarepresentation: Native competence and targets for instruction. Cognition and Instruction, 22(3), 293-331.

Dolphin, G., \& Benoit, W. (2016). Students' mental model development during historically contextualized inquiry: How the 'tectonic plate' metaphor impeded the process. International Journal of Science Education, 38(2), 276-297.

Duit, R., Treagust, D., \& Widodo, A. (2013). Teaching science for conceptual change: Theory and practice. In S. Vosniadou (Ed.), International handbook of research on conceptual change ( $2^{\text {nd }}$ ed., pp. 487-503). New York, NY: Routledge.

Duschl, R., Maeng, S., \& Sezen, A. (2011). Learning progressions and teaching sequences: A review and analysis. Studies in Science Education, 47(2), 123-182.

Francek, M. (2013). A compilation and review of over 500 geoscience misconceptions. International Journal of Science Education, 35(1), 31-64.

Froyland, M., Remmen, K., \& Sorvik, G. (2016). Name dropping or understanding?: Teaching to observe geologically. Science Education, 100(5), 923-951. 
Gilbert, J., Osborne, R., \& Fensham, P. (1982). Children's science and its consequences for teaching. Science Education, 66(4), 623-633.

Gillies, R. M. (2016). Dialogic interactions in the cooperative classroom. International Journal of Educational Research, 76, 178-189.

Gobert, J. (2000). A typology of causal models for plate tectonics: Inferential power and barriers to understanding. International Journal of Science Education, 22(9), 937-977.

Harlen, W. (2010). Principles and big ideas of science education. Retrieved from https://www.ase.org.uk/resources/big-ideas/

Hoban, G. (2005). From claymation to slowmation: A teaching procedure to develop students' science understandings. Teaching Science, 51(2), 26-30.

Hoban, G. (2007). Using slowmation to engge preservice elementary teachers in understanding science content knowledge. Contemporary Issues in Technology and Teacher Education, $7(2), 1-9$.

Hoban, G., Ferry, B., Konza, D., \& Vialle, W. (2007). Slowmation: Exploring a new teaching approach in primary school classrooms. Paper presented at the Australian Teacher Education Association Conference, Wollongong, NSW.

Hoban, G., Loughran, J., \& Nielsen, W. (2011). Slowmation: Preservice elementary teachers representing science knowledge through creating multimodal digital animations. Journal of Research in Science Teaching, 48(9), 985-1009.

Hoban, G., \& Nielsen, W. (2010). A new teaching approach to encourage slowmations (studentgenerated animations) of science concepts. Teaching Science, 56(3), 33-38.

Hoban, G., \& Nielsen, W. (2012). Using "slowmation" to enable preservice primary teachers to create multimodal representations of science concepts. Research in Science Education, 42(6), 11011119.

Hoban, G., \& Nielsen, W. (2013). Learning science through creating a 'slowmation': A case study of preservice primary teachers. International Journal of Science Education, 35(1), 119-146.

Hoban, G., \& Nielsen, W. (2014). Creating a narrated stop-motion animation to explain science: The affordances of "slowmation" for generating discussion. Teaching and Teacher Education, 42, 68-78.

Jablonski, D., Hoban, G., Ransom, H. \& Ward, K. (2015). Exploring the use of slowmation as a pedagogical alternative in science teaching and learning. Pacific-Asian Education, 27, 5-20.

Kidman, G. \& Hoban, G. (2009). Biotechnology learnings using 'claymation' and 'slowmation'. Paper presented at the National Association for Research in Science Teaching Conference, Orange County, CA.

Loughran, J., Berry, A., Cooper, R., Keast, S., \& Hoban, G. (2012). Preservice teachers learning about teaching for conceptual change through slowmation. Asia-Pacific Forum on Science Learning and Teaching, 13(1), 1-28.

Mills, R. (2017). Representing Earth science concepts using slowmation: Influences on middle school students' conceptual change (unpublished PhD thesis). James Cook University, Townsville, Australia. doi: 10.4225/28/5afa39a6b90ec

Mills, R., Tomas, L., \& Lewthwaite, B. (2017). Junior secondary school students' conceptions about plate tectonics. International Research in Geographical and Environmental Education, 26(4), 297-310.

Mills, R., Tomas, L., \& Lewthwaite, B. (2016). Learning in Earth and space science: A review of conceptual change instructional approaches. International Journal of Science Education, 38(5), 767-790.

Nichols, K., Gillies, R., \& Hedberg, J. (2016). Argumentation-based collaborative inquiry in science through representational work: Impact of primary students' representational fluency. Research in Science Education, 46(3), 343-364. 
Nielsen, W., \& Hoban, G. (2015). Designing a digital teaching resource to explain phases of the moon: A case study of preservice elementary teachers making a slowmation. Journal of Research in Science Teaching, 52(9), 1207-1324.

Nielsen, W., Hoban, G., \& Hyland, C. (2017). Pharmacology students' perceptions of creating multimodal digital explanations. Chemistry Education Research and Practice, 18, 329-339.

Nunnally, J. (1978). Psychometric theory (2 ${ }^{\text {nd }}$ Ed.). New York, NY: McGraw-Hill.

Ogan-Bekiroglu, F. (2007) Effects of model-based teaching on pre-service physics teachers' conceptions of the moon, moon phases, and other lunar phenomena. International Journal of Science Education, 29(5), 555-593.

Osborne, R., \& Gilbert, J. (1979). Investigating student understanding of basic physics concepts using an interview-about-instances technique. Research in Science Education, 9(1), 85-93.

Paige, K., Bentley, B., \& Dobson, S. (2016). Slowmation: An innovative twenty-first century learning tool for science and mathematics pre-service teachers. The Australian Journal of Teacher Education, 41(2), 1-15.

Plummer, J., \& Maynard, L. (2014). Building a learning progression for celestial motion: An exploration of students' reasoning about the seasons. Journal of Research in Science Teaching, 51(7), 902-929.

Plummer, J., Palma, C., Flarend, A., Rubin, K., Ong, Y., Botzer, B., McDonald, S., \& Furman, T. (2015). Development of a learning progression for the formation of the solar system. International Journal of Science Education, 37(9), 1381-1401.

Prain, V., \& Tytler, R. (2012). Learning through constructing representations in science: A framework of representational construction affordances. International Journal of Science Education, 34(17), 2751-2773.

Saldaña, J. (2013). The coding manual for qualitative researchers ( $2^{\text {nd }}$ ed.). Thousand Oaks, CA: Sage.

Stake, R. (1995). The art of case study research. Thousand Oaks, CA: Sage.

Tabachnick, B., \& Fidell, L. (2007). Using multivariate statistics ( $5^{\text {th }}$ ed.). Boston, MA: Allyn \& Unwin.

Taylor, P. (2015). Constructivism. In R. Sunstone (Ed.), Encyclopaedia of science education (pp. 218-224). Netherlands: Springer.

Tippett, C. (2016). What recent research on diagrams suggests about learning with rather than learning from visual representations in science. International Journal of Science Education, $38(5), 725-746$.

Treagust, D. (1988). Development and use of diagnostic tests to evaluate students' misconceptions in science. International Journal of Science Education, 10(2), 159-169.

Treagust, D. (2006). Diagnostic assessment in science as a means to improving teaching, learning and retention. Paper presented at the Australian Conference on Science and Mathematics Education, Sydney, NSW.

Trundle, K., Atwood, R., \& Christopher, J. (2002). Pre-service elementary teachers' conceptions of moon phases before and after instruction. Journal of Research in Science Teaching, 39(7), 633-658.

Trundle, K., \& Bell, R. (2010). The use of a computer simulation to promote conceptual change: A quasi-experimental study. Computers and Education, 54(4), 1078-1088.

Tsai, C., \& Chang, C. (2005). Lasting effects of instruction guided by the conflict map: Experimental study of learning about the causes of the seasons. Journal of Research in Science Teaching, 42(10), 1089-1111.

Tsui, C., \& Treagust, D. (2010). Evaluating secondary students' scientific reasoning in genetics using a two-tier diagnostic instrument. International Journal of Science Education, 32(8), 10731098. 
Ucar, S., Trundle, K., \& Krissek, L. (2011). Inquiry-based instruction with archived, online data: An intervention study with preservice teachers. Research in Science Education, 41(2), 261-282.

Vosniadou, S. (2013). Conceptual change in learning and instruction: The framework theory approach. In S. Vosniadou (Ed.), International handbook of research on conceptual change ( $2^{\text {nd }}$ ed., pp. 11-30). New York, NY: Routledge.

Wishart, J. (2017). Exploring how creating stop-motion animations supports student teachers in learning to teach science. Journal of Research on Technology in Education, 49(1-2), 88-101.

Yoon, S., \& Peate, D. (2015). 'Teaching what I learned': Exploring students Earth and Space Science learning experiences in secondary school with a particular on their comprehension of the concept of 'geologic time'. International Journal of Science Education, 37(9), 1436-1453. 